\title{
SOFCEV: Conventional LCC reduction and NPV based on savings in fixed carbon by sugarcane
}

\author{
SOFCEV: Reducción de LCC y VPN basada en ahorros en fijación de carbono por plantaciones
}

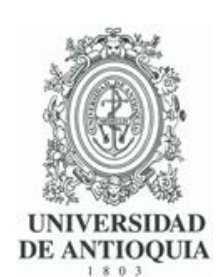

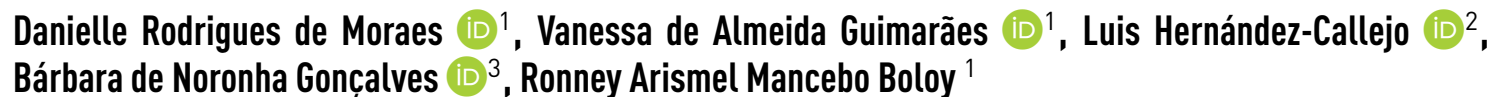

${ }^{1}$ Federal Centre of Technological Education Celso Suckow da Fonseca. Avenida Maracanã, 229 Maracanã. P. C. $20271-110$. Rio de Janeiro, Brasil.

${ }^{2}$ Universidad de Vallodolid. C/Plaza de Santa Cruz, 8. C. P. 47002. Valladolid, España.

${ }^{3}$ Universidade Federal do Rio de Janeiro. Avenida Pedro Calmon, 550. P. C. 21941-901. Rio de Janeiro, Brasil.

\section{CITE THIS ARTICLE AS:}

D. Rodrigues, V. de Almeida, L. Hernández, B. de Noronha and R. A. Mancebo. SOFCEV:

Conventional LCC reduction and NPV based on savings in fixed carbon by sugarcane, Revista Facultad de Ingeniería Universidad de Antioquia, no. 105, pp. 47-59, Oct-Dec 2022. [Online]. Available: https: //www.doi.org/10.17533/ udea.redin. 20210952

\section{ARTICLE INFO:}

Received: January 19, 2021 Accepted: September 03, 2021 Available online: September 03, 2021

\section{KEYWORDS:}

Life cycle cost; carbon credits; solid oxide fuel cell electric vehicle; carbon dioxide emissions; sugarcane ethanol

Costo del ciclo de vida; créditos de carbono; vehículo eléctrico de celda de combustible de óxido sólido; emisiones de dióxido de carbono; etanol de caña de azúcar
ABSTRACT: Carbon pricing is a cost-effective method for mitigating climate impacts. This article examines the conventional life cycle cost (LCC), net present value (NPV), and carbon dioxide $\left(\mathrm{CO}_{2}\right)$ emissions of the Solid Oxide Fuel Cell Electric Vehicle (SOFCEV) powered by Brazilian fuels. The cost reduction potential of the SOFCEV was evaluated, considering the Brazilian productivity of sugarcane and the carbon fixed by these plantations, through the mechanism of carbon credits sale. Sugarcane ethanol and gasoline C $173 \%$ gasoline A and $27 \%$ anhydrous ethanol) were considered. Three scenarios were outlined: al Cost of investment, fuel production, and vehicle maintenance and operation in USD/km, over a 10-year amortization period; b) SOFCEV emission cost from well-to-wheel added to cost (a); c) Cost of carbon fixed by hectares of sugarcane in Brazil necessary to supply the fuel demand of the SOFCEV subtracted from (b). Results showed that the ethanol-fuelled SOFCEV attends the carbon-neutral cycle, since the carbon credit sale resulted in an avoided cost 1.1 times higher than the emissions cost. Gasoline $C$ showed similar results for the three scenarios, with an emission cost 2.5 times higher than the avoided cost. Carbon pricing was not sufficient to make the technology more viable for consumer, with an expected NPV of -USD 8006.38 after the amortization period. Thus, it is expected to obtain economic indicators to encourage the use of biofuels in electric fleets.

RESUMEN: La tarificación del carbono es un método rentable para mitigar los impactos climáticos. Este artículo examina el costo del ciclo de vida convencional (LCC), el valor actual neto (NPV) y las emisiones de dióxido de carbono $\left(\mathrm{CO}_{2}\right)$ del vehículo eléctrico de celda de combustible de óxido sólido (SOFCEV). Se evaluó el potencial de reducción de costos del SOFCEV, considerando la productividad brasileña de caña de azúcar y la fijación de carbono por estas plantaciones, mediante el mecanismo de venta de créditos de carbono. Se delinearon tres escenarios: al Costo de inversión, producción de combustible, mantenimiento y operación del vehículo en USD/km, en un período de amortización de 10 años; b) Costo de emisión producida en el SOFCEV desde el pozo a la rueda agregado al coste de (a); c) Costo del carbono fijado por hectáreas de caña de azúcar necesario para abastecer el SOFCEV restado de (b). El SOFCEV alimentado con etanol alcanza la neutralidad de carbono, con un costo evitado 1,1 veces mayor que el costo de las emisiones. La gasolina $\mathrm{C}$ mostró un costo de emisiones 2.5 veces mayor que el costo reducido. El precio del carbono no fue suficiente para que la tecnología fuera más viable para el consumidor, con un NPV esperado de -USD 8006.38 en 10 años. Así, se espera obtener indicadores económicos para incentivar el uso de biocombustibles en las estaciones de carga eléctrica.

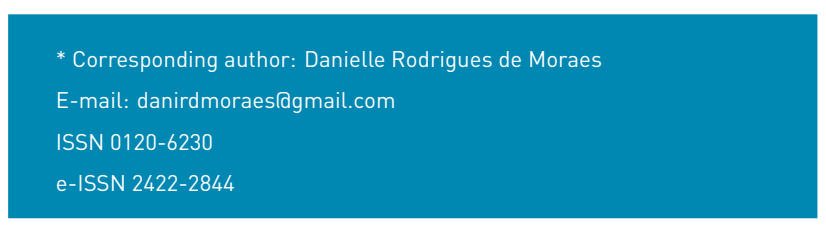




\section{Introduction}

In recent years, the actions resulting from economic and industrial activities have caused several negative impacts on the dynamics of ecosystems, particularly regarding the emission of greenhouse gases (GHG). Some of these impacts are extreme weather conditions such as prolonged droughts, rising sea levels, increased forest fires, changes in the rain regime, and agricultural patterns, among others [1]. The world's energy matrix will have to undergo transformations to slow the increase in the global average temperature; this can be achieved by the adoption of green alternatives until the level of zero net emissions can be reached. According to the International Renewable Energy Agency [2], in order to maintain global warming below $2^{\circ} \mathrm{C}$ until 2050, it is mandatory that, by 2030, the proportion of bioenergy in relation to global energy consumption be doubled and triple the use of biofuels for the transport sector.

However, internal combustion engine vehicles (ICEV) dominate the Brazilian fleet of non-commercial light-duty vehicles (LDV) and, despite the success in using ethanol in flex vehicles, there is still a large share of inefficient ICEV with obsolete technologies that operate without remarkable fuel economy, and consequently with high exhaust emissions [3]. According to Souza et al. [4], it is estimated that LDV fuel consumption in Brazilian urban roads is around $3.77 \mathrm{MJ} / \mathrm{km}$, while in the review made by Rosenfeld et al. [5], modern LDV have an average consumption of $1.60 \mathrm{MJ} / \mathrm{km}$. Consequently, the main source of emissions in the Brazilian energy sector is transport, having been responsible for the emission of 200.2 million tons of carbon dioxide equivalent $\left(\mathrm{CO}_{2}\right.$ eq.) in 2018 , which represents $49 \%$ of the total emitted [6].

Thus, it is understood that electromobility would play an important role in the decarbonization of the transport sector, as it combines technologies with low or zero exhaust emissions. The number of electric vehicles in circulation in early 2018 increased by $63 \%$ over the same period last year worldwide [7]. However, this increase is not uniform across the globe, with many countries lagging behind due to factors such as the lack of infrastructure and incentives for technologies that best serve a certain national scenario. In economic terms, the ICEV still has a more competitive selling price than electric and hybrid vehicles (around $40 \%$ more expensive), in addition to the high initial investment cost in local infrastructure for charging and adapting the electrical matrix [7].

According to the review conducted by Guimarães [8], some policies and actions can be adopted to mitigate emissions, especially in the transport sector, such as: (i) carbon emission regulation policies le.g., carbon tax, carbon cap, and carbon cap-and-trade); (ii) use of renewable fuels (i.e., biofuels); (iii) increased vehicle energy efficiency; (iv) emissions inventory; (v) actions in the transport infrastructure, vehicle technology, and management, aiming to reduce these emissions. According to the World Bank [9], the carbon pricing policy represents the internalization of social costs resulting from $\mathrm{GHG}$ emissions, establishing a value for the ton of $\mathrm{CO}_{2}$ Equation emitted. This social cost includes all expenses directed to society that may be related to climate change, such as the repair of territorial damage caused by floods or forest fires, and expenses resulting from damage to health caused by heat waves.

In addition, carbon pricing is a regulatory instrument that generates cost-effectiveness gains, i.e., it demonstrates mitigation potential by directing consumer demands and investments to services and technologies with a lower carbon footprint [10]. Carbon pricing in Brazil has been in development since 2011, with the establishment of a preliminary proposal to prepare the market for its implementation [11]. Regarding the transport sector, the National Biofuels Policy (RenovaBio) plays an important role through the implementation of Decarbonization Credits (CBIO), which apply to Brazilian producers and importers of biofuels certified by RenovaBio. This instrument aims to value efficient agents in the biofuels market and generate incentives to reduce the carbon intensity of their production process each year [12]. According to projections by the International Council on Clean Transportation, the CBIO provide incentives for better performing sugarcane ethanol producers, with an emphasis on bagasse ethanol (i.e., second-generation ethanoll producers which generates $95 \%$ carbon savings over fossil gasoline [13].

Among the cleanest electric vehicle technologies, the Battery Electric Vehicle (BEV) and the Hydrogen Fuel Cell Electric Vehicle (HFCEV) are considered, which have zero exhaust emissions. The commercially available HFCEV models operate with the Proton Exchange Membrane Fuel Cell, a low-temperature fuel cell, with a temperature range between $40^{\circ} \mathrm{C}$ and $100^{\circ}$, that must be fed directly with hydrogen and presents only water and heat as exhaust emissions [14]. However, one of the biggest challenges for the massive adoption of HFCEV is the lack of hydrogen supply infrastructure [15]. The Solid Oxide Fuel Cell Electric Vehicle (SOFCEV) emerge as an alternative for countries with prospects for the development of electromobility and a well-established biofuel market. Due to the operating temperature range between $850^{\circ} \mathrm{C}$ and $1000{ }^{\circ} \mathrm{C}$ of the Solid Oxide Fuel Cell (SOFC), the surplus heat can be used to produce hydrogen on-board through the internal steam-reforming of hydrocarbon fuel (e.g., biomethane and gasoline) or alcohol fuels (e.g., 
ethanol and glycerine) [14]. This technology is suitable for countries with a strong biofuel market, such as Brazil.

Thus, it is believed that the SOFCEV could be adopted as an alternative to the Brazilian context, since it is a technology that values both the sugarcane ethanol produced in the country and the use of electromobility, without the requirement for significant changes in the local supply infrastructure [16]. There is also the possibility of reducing costs based on obtaining and selling carbon credits, which tends to favor biofuel producers.

This article examines the conventional life cycle cost (LCC) and carbon dioxide $\left(\mathrm{CO}_{2}\right)$ emissions of the SOFCEV powered by Brazilian fuels. It is an extension of the study presented at the III Ibero-American Congress on Smart Cities entitled "Solid Oxide Fuel Cell Electric Vehicle: Cost Reduction Based on Savings in Fixed Carbon by Sugarcane" as it examines, additionally, the economic viability of the SOFCEV for consumers by assessing the net present value (NPV) [16]. Thus, it is expected to obtain economic and environmental indicators to encourage the use of biofuels in the Brazilian transport sector, specifically in electromobility.

\section{Methodology and assumptions adopted}

The analysis was based on the conventional LCC method for the SOFCEV, assuming capital investments (capital costs), vehicle manufacturing cost, maintenance and operating costs, fuel production cost, and well-to-wheel (WTW) emissions cost. The fuels considered were Brazilian sugarcane ethanol and gasoline C (73\% gasoline and $27 \%$ anhydrous sugarcane ethanol on a volume basis). The potential for cost reduction was evaluated considering the cost avoided through the acquisition and sale of carbon credits, when dealing with the Brazilian productivity of sugarcane and the carbon fixed by these plantations. Also, to analyze the economic feasibility for the consumers, the NPV was estimated assuming the expenses through the purchase of the vehicle.

\subsection{SOFCEV operation and specifications}

Inside the SOFC with a fuel processor, several reactions occur, such as steam-reforming, water-gas shift, and electrochemical reactions. These reactions are designed to produce a gas mixture that mainly contains hydrogen $\left(\mathrm{H}_{2}\right), \mathrm{CO}_{2}$, and carbon monoxide (CO). The hydrogen supplied after the fuel steam-reforming process via the anode side reacts with the atmospheric air from the cathode side to produce electricity and heat. The electricity produced to charge the battery and the heat is recovered in the form of energy through the appropriate technology (e.g., gas turbine). This energy is taken to the fuel processor, where the internal production of hydrogen is restarted.

Figure 1 shows a simplified SOFC scheme with a gas turbine. The model described by Facchinetti et al. [17] includes a fuel processor where partial steam-reforming of the fuel occurs, including auxiliary devices (i.e., pump and blowers) and excessive steam to guarantee a reduced rate of degradation of the planar SOFC. The use of heat exchangers is necessary to remove the extra energy generated during the operation of the system. Unused fuel is directed to a burner where it is oxidized, as the expansion of the hot gases activates the turbine, ejecting the exhaust gases into the atmosphere.

The basic operation principle of the SOFC is based on three main reactions. These reactions are as follows:
$\mathrm{H}_{2} \rightarrow 2 \mathrm{H}^{+}+2 \mathrm{e}^{-}$
(Reaction 1)
$1 / 2 \mathrm{O}_{2}+2 \mathrm{e}^{-} \rightarrow \mathrm{O}^{2-}$
(Reaction 2)

The $H_{2}$ produced upstream is pumped to the fuel cell anode, where it is oxidized and separated into two hydrogen protons $\left(\mathrm{H}^{+}\right)$and two electrons $\left(2 e^{-}\right)$, as described in Reaction 1 [18]. The oxygen $\left(\mathrm{O}_{2}\right)$ enters the fuel cell through the positive terminal, the cathode, where it is reduced forming two oxide ions $\left(\mathrm{O}^{2-}\right)$, as in Reaction 2 [18]. Each $\mathrm{O}^{2-}$ attracts two $\mathrm{H}+$ through the electrolyte, which combine to form the water molecule $\left(\mathrm{H}_{2} \mathrm{O}\right)$ in an exothermic reaction. These reactions together form an electron flow, as the electrons formed at the anode bypass the fuel cell electrolyte and return to the cathode, generating an electric current. This process can be resumed in an overall electrochemical cell reaction, as in Reaction 3 [18].

$\mathrm{H}_{2}+1 / 2 \mathrm{O}_{2} \rightarrow \mathrm{H}_{2} \mathrm{O}$

(Reaction 3)

In addition, conventional vehicles (i.e., ICEV) operate with low efficiency, around 30-35\% [14], while the efficiency observed by Facchinetti et al. [17] in SOFC with gas turbines was between $60-72 \%$. Therefore, it is expected that the SOFC vehicle application will meet increasingly restrictive efficiency and fuel economy standards.

\subsection{SOFCEV Life Cycle Cost Calculation System}

The vehicle LCC considers the financial expenses in stages such as preparing the infrastructure, manufacturing, producing the energy source (i.e., fuel or electricity), as well as the expenses resulting from its maintenance and operation, as explained in Figure 2. From WTW, there are essential expenses and $\mathrm{GHG}$ emissions intrinsic to 


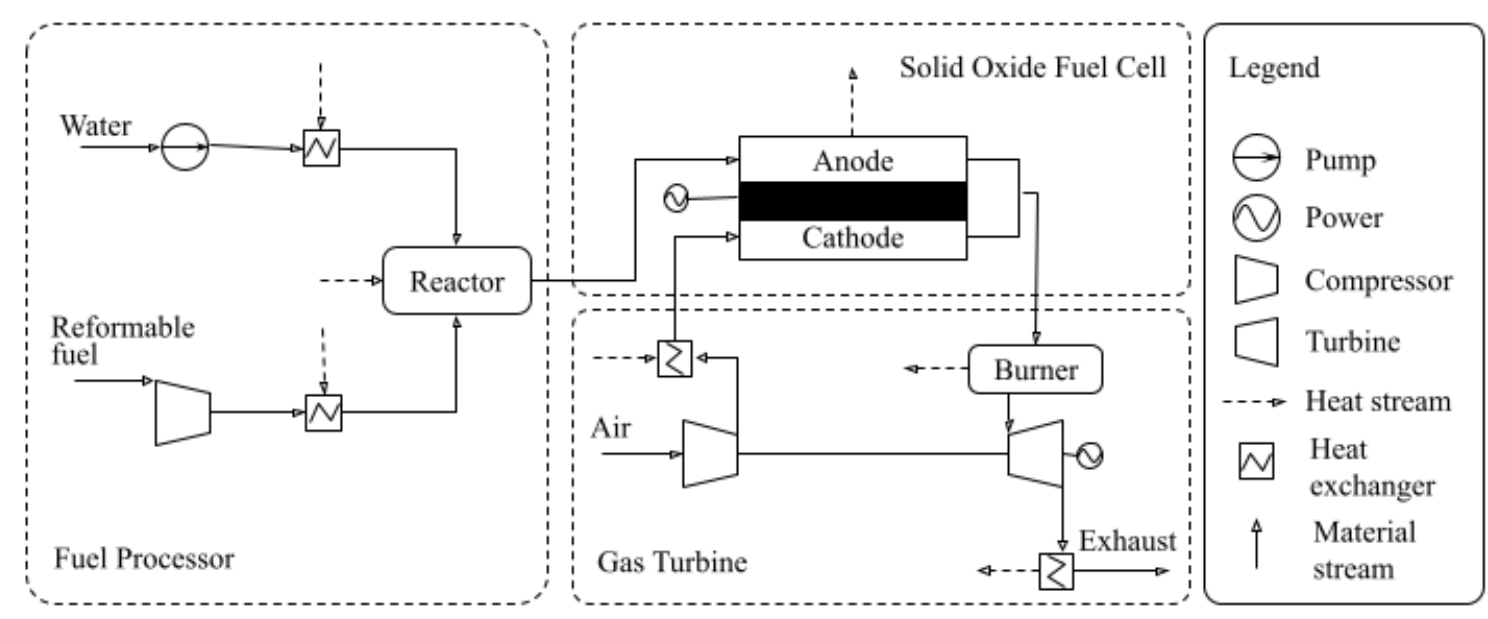

Figure 1 Simplified Solid Oxide Fuel Cell Scheme with Gas Turbine [17].

the main stages of the SOFCEV dissemination: vehicle manufacture, generation and transportation of fuel, and circulation of the SOFCEV. The cost of manufacturing, preparation of infrastructure, as well as maintenance and operation of the SOFCEV were obtained through equations by different authors. The emissions inventory related to the cultivation of sugarcane, generation, and transportation of fuel was prepared based on data available in the literature, specifically for the Brazilian scenario.

\section{Scenario A}

This scenario includes the cost of investing in equipment, producing Brazilian fuels, manufacturing, maintaining, and operating the vehicle. This cost will be presented in USD $/ \mathrm{km}$, considering anhydrous sugarcane ethanol and gasoline C $173 \%$ gasoline and $27 \%$ anhydrous sugarcane ethanol on a volume basis) as fuel, during a 10-year amortization period.

The vehicle volumetric fuel flow was obtained through Equation (1) from Braga [19], as follows:

$$
\dot{\mathrm{m}}=3.6 \cdot \frac{P_{S O F C}}{\eta_{S O F C} \cdot \rho_{f} \cdot L H V_{f}}
$$

Where $\dot{m}$ is the volumetric fuel flow of the SOFCEV in $m^{3} / h ; P_{S O F C}$ is the SOFC power in $k W ; \eta_{S O F C}$ is the average efficiency of the SOFC with heat recovery; $\rho_{f}$ is the fuel density in $\mathrm{kg} / \mathrm{m}^{3} ; L H V_{f}$ is the fuel lower heating value in $M J / \mathrm{kg}$.

Equation (2) e Equation (3) from Boloy et al. [20] were used to estimate the manufacturing cost over a 10-year amortization period:

$$
\begin{gathered}
q=1+\frac{r}{100} \\
f=\frac{q^{k} \cdot(q-1)}{q^{k}-1}
\end{gathered}
$$

Where $r$ represents the annual interest rate of $3.75 \%$, referring to the Selic rate for April 2020; $f$ represents the annuity factor in 1/year; $q$ represents the capital value; $k$ represents the amortization period in years. The manufacturing cost, fuel production cost, and the maintenance and operation cost are determined by Equation (4), Equation (5), and Equation (6), below:

$$
\begin{gathered}
C_{v}=\frac{C_{\mathrm{SOFCEV}}}{\Delta S} \cdot f \\
C_{f}=\frac{\dot{\mathrm{m}} \cdot C_{f}^{\prime}}{v} \\
C_{M \& O}=\% M \& O \cdot C_{v}
\end{gathered}
$$

Where $C_{v}$ represents the cost of vehicle equipment and components in USD $/ \mathrm{km}$; $C_{S O F C E V}$ represents the total manufacturing cost of the SOFCEV in USD; $\triangle S$ represents the vehicle life cycle in $\mathrm{km} /$ year, considering a life cycle of $150000 \mathrm{~km}$ in 10 years; $C_{f}$ represents the fuel production cost in $U S D / \mathrm{km}_{\text {; }} C_{f}^{\prime}$ represents the fuel production cost in $U S D / m^{3} ; v$ represents the average speed of LDV on urban roads as $40 \mathrm{~km} / \mathrm{h}$, according to the Brazilian Traffic Code [21]; $C_{\% M \& O}$ represents the portion referring to the cost of maintenance and operation in USD/km; and $\% M \& O$ is the percentage of the vehicle equipment and components cost that represents the cost of maintenance and operation, adopted as $10 \%$ [22].

Therefore, adapting the methodology used by Braga [19] and Micena [22], the total cost of Scenario A is described by Equation (7):

$$
C_{a}=\left[1.23 \cdot\left(C_{v}+C_{M \& O}\right)\right]+C_{f}
$$

Where $C_{a}$ represents the total cost of Scenario A over a 10 -year amortization period. For a more realistic analysis, 


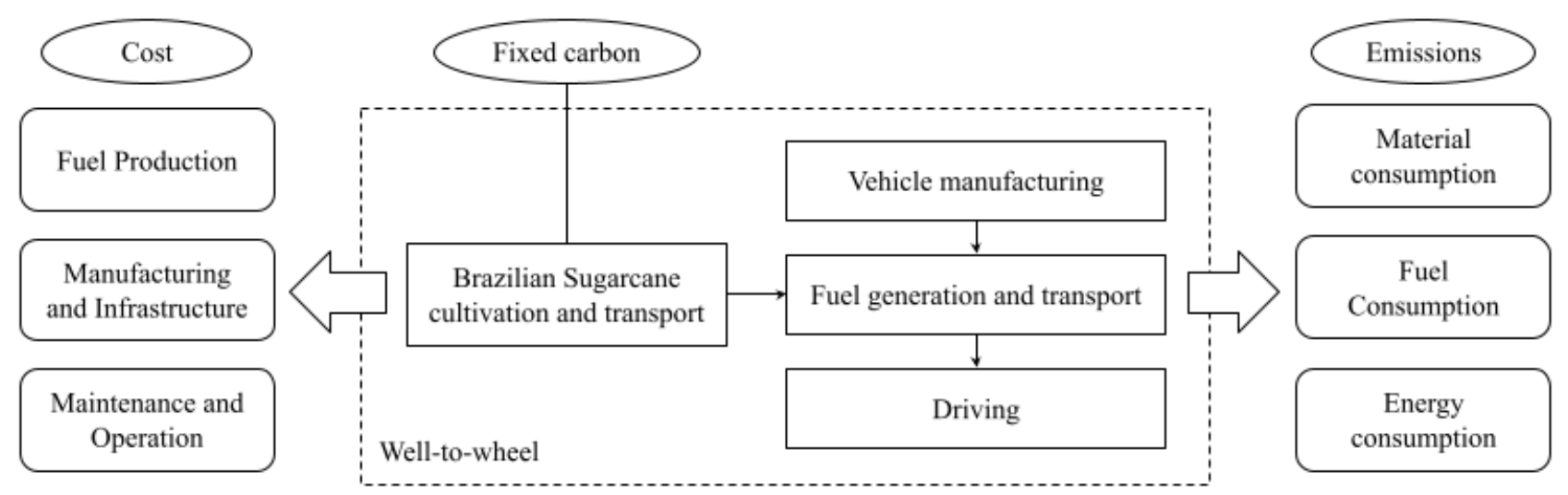

Figure 2 Scope and calculation system.

the coefficient 1.23 was adopted, which includes additional expenses of $23 \%$ on investments in equipment, including land preparation (5\%), design and engineering $(10 \%)$, contingency (5\%), and permission (3\%) [22].

\section{Scenario B}

In this scenario, the emissions cost is added to $C_{a}$. Thus, the social cost resulting from the negative effects of the anthropogenic GHG emissions is now internalized, i.e., from the carbon taxation mechanism, WTW emissions of the SOFCEV are accounted for and taxed, without the acquisition of carbon credits. WTW emissions range from fuel production to vehicle circulation on urban roads.

Tank-to-wheel (TTW) emissions include the steps after the vehicle is supplied, i.e., the vehicle circulation and, eventually, the disposal or recycling of components. In this study, the TTW analysis includes only the exhaust emissions of the SOFCEV, obtained through Equation (1) and the reactions that occur inside the SOFCEV. The hydrocarbon or alcohol fuel inserted into the fuel cell undergoes a steam-reforming reaction to produce $\mathrm{H}_{2}$, and the $C O$ eventually formed during this process is consumed by the water-shift reaction, producing more $\mathrm{H}_{2}$ $[23,24]$.

The equations for ethanol $\left(\mathrm{C}_{2} \mathrm{H}_{5} \mathrm{OH}\right)$ steam-reforming (Reaction 4) and water-gas shift reaction (Reaction 5) are as follow $[25,26]$

$$
\begin{array}{lc}
\mathrm{C}_{2} \mathrm{H}_{5} \mathrm{OH}+\mathrm{H}_{2} \mathrm{O} \rightarrow 2 \mathrm{CO}+4 \mathrm{H}_{2} & \text { (Reaction 4) } \\
2 \mathrm{CO}+2 \mathrm{H}_{2} \mathrm{O} \rightarrow 2 \mathrm{CO}_{2}+2 \mathrm{H}_{2} & \text { (Reaction 5) }
\end{array}
$$

The octane $\left(\mathrm{C}_{8} \mathrm{H}_{18}\right)$ is used as a gasoline surrogate for gasoline processing simulation, and the equations for octane steam-reforming (Reaction 6) and water-gas shift reaction (Reaction 7) are as follow [27, 28]:
$\mathrm{C}_{8} \mathrm{H}_{18}+8 \mathrm{H}_{2} \mathrm{O} \rightarrow 8 \mathrm{CO}+17 \mathrm{H}_{2}$ (Reaction 6)

$8 \mathrm{CO}+8 \mathrm{H}_{2} \mathrm{O} \rightarrow 8 \mathrm{CO}_{2}+8 \mathrm{H}_{2}$ (Reaction 7)

Therefore, the following global steam-reforming reactions were obtained for ethanol and gasoline, respectively $[27,28]$ :

$$
\mathrm{C}_{2} \mathrm{H}_{5} \mathrm{OH}+3 \mathrm{H}_{2} \mathrm{O} \rightarrow 2 \mathrm{CO}_{2}+6 \mathrm{H}_{2}
$$

(Reaction 8)

$$
\mathrm{C}_{8} \mathrm{H}_{18}+16 \mathrm{H}_{2} \mathrm{O} \rightarrow 8 \mathrm{CO}_{2}+25 \mathrm{H}_{2}
$$

(Reaction 9)

From the chemical reactions described above, it is possible to arrive at the $\mathrm{CO}_{2}$ emission factor, in $\mathrm{kg}$ of $\mathrm{CO}_{2}$ eq. per $\mathrm{kg}$ of fuel, calculated by Equation (8) [29]. Here, the $\mathrm{CO}_{2}$ emissions are considered as $\mathrm{CO}_{2}$ eq. emissions, since there are no emissions of methane, sulphur dioxide, nitrogen dioxide and particulates present in this simulated process. Additionally, the complete steam-reforming in the fuel processor was considered for simplification purposes. In practice, a small amount of fuel remains downstream of the SOFC due to incomplete reforming, thus, this remaining fuel is burned in the combustion chamber of the SOFCEV [17].

$$
f_{C O 2 e}=\frac{n_{C O 2} \cdot M_{C O 2}}{n_{f} \cdot M_{f}}
$$

Where $f_{C O 2 e}$ represents the steam-reforming emission factor in $\mathrm{kg}$ of $\mathrm{CO}_{2}$ eq. per $\mathrm{kg}$ of fuel; $\eta_{\mathrm{CO} 2}$ and $\eta_{f}$ represent the number of moles of $\mathrm{CO}_{2}$ and fuel, respectively, obtained from Reaction 8 and Reaction 9; $M_{C O 2}$ and $M_{f}$ are the molecular weight of $\mathrm{CO}_{2}$ and fuel in $\mathrm{g} / \mathrm{mol}$. The values calculated from Equation (8) for ethanol and gasoline were $1.91 \mathrm{~kg} \mathrm{CO}$ eq. $/ \mathrm{kg}$ and $3.08 \mathrm{~kg} \mathrm{CO}_{2}$ eq. $/ \mathrm{kg}$, respectively. The total cost of Scenario $B$ is given by Equation (9), as follows: 


$$
C_{b}=C_{a}+\left(U S D_{C O 2} \cdot \frac{\dot{m} \cdot f_{C O 2 e} \cdot \rho_{f}}{v}\right)
$$

Where $C_{b}$ represents the total cost of Scenario B in USD/km; $U S D_{\mathrm{CO} 2}$ is the rate attributed to the $\mathrm{kg}$ of $\mathrm{CO}_{2}$ emitted in USD/kg $\mathrm{CO}_{2} ; \rho_{f}$ is the fuel density in $\mathrm{kg} / \mathrm{m}^{3}$.

Well-to-tank emissions (i.e., vehicle, battery, ethanol, and gasoline production), as well as the estimate of TTW emissions (i.e., exhaust gas emissions) for the SOFCEV are explained in Table 1. The TTW emission of the vehicle was calculated considering volumetric fuel flow, steam-reforming emission factor, fuel density, and the average speed of LDV on urban roads according to the Brazilian Traffic Code.

\section{Scenario C}

In this scenario, the carbon fixed by sugarcane plantations will be counted when considering the Brazilian sugarcane ethanol pathway. Carbon fixation is the photosynthetic reaction that occurs between atmospheric $\mathrm{CO}_{2}$ and water to generate organic products needed by plants. Thus, Equation (10) presents the adaptation of the methodology used by Neamhom et al. [31] and the United States Environmental Protection Agency [32] to estimate carbon fixation by sugarcane plantations:

$$
C F=0.4 \cdot\left(\frac{44 k g C O_{2}}{12 k g C}\right) \cdot Y
$$

Where $\mathrm{CF}$ represents the carbon fixation per hectare of sugarcane in $\mathrm{kgCO} 2 / \mathrm{ha} ; 0.4$ is the conversion factor, which is a ratio of carbon in biomass in the photosynthetic reaction, as follows: $\mathrm{CO}_{2}+\mathrm{H}_{2} \mathrm{O} \rightarrow$ $\mathrm{CH}_{2} \mathrm{O}+\mathrm{O}_{2} ;(44 \mathrm{kgCO} / 2 / 12 \mathrm{kgC})$ is the ratio of the molecular weight of carbon dioxide to carbon; $Y$ is the sugarcane productivity per hectare in $\mathrm{kg} / \mathrm{ha}$.

To estimate the cost of fixed carbon when meeting the SOFCEV ethanol demand, Equation (11) was used, as follows:

$$
C_{f c}=R \$_{C O 2} \cdot \frac{C F \cdot V_{f}}{A P \cdot S}
$$

Where $C_{f c}$ represents the economy based on the carbon fixed by sugarcane plantations during the production of the ethanol needed to supply the SOFCEV demand in USD/km; $V_{f}$ represents the volume of ethanol consumed during the vehicle life cycle in $m^{3}$; $A P$ represents the agro-industrial productivity of Brazilian ethanol in $\mathrm{m}^{3} / \mathrm{ha}$; S represents the vehicle life cycle in $\mathrm{km}$. Therefore, the total cost of Scenario $\mathrm{C}$ is determined by Equation (12), as follows:

$$
C_{c}=C_{b}-C_{f c}
$$

Where $C_{c}$ represents the total cost of Scenario C, considering the carbon fixed by sugarcane plantations during ethanol production in USD/km. Through Equation (12) the existence of a simplified market for the sale of carbon credits is considered. In this case, it would be possible to sell the credits referring to the fixed carbon value, and thus deduct from the total costs. However, it is assumed that there is no maximum emissions limit for the sector (cap). The additional costs resulting from the operation of the carbon market due to the lack of regulation worldwide have not been considered. In Brazil there are recent sectorial initiatives such as the decarbonization credits from RenovaBio, aimed at the certification of producers and importers of biofuels in the country [12].

\subsection{Net Present Value}

To analyse the economic feasibility of the SOFCEV in the Brazilian scenario, the NPV method was used. Economically speaking, a present value represents the estimate of how much a future expense is worth in the present, considering the value of money over time through a discount rate [33]. Therefore, the higher the NPV, the greater the business viability. The following Equations were used to determine the NPV for the final consumer [34]

$$
\begin{gathered}
N P V=-C i+\sum_{t=1}^{n} \frac{C t}{(1+i)^{t}} \\
C t=C f^{\prime \prime}+C m+C r
\end{gathered}
$$

Where $C i$ is the SOFCEV purchase price, in USD, considering $10 \%$ profit for the manufacturer; $C t$ is the cost of maintenance and operation of the vehicle in USD/year; $i$ is the discount rate for the Brazilian scenario, adopted as $12.7 \%$ [35]; $t$ is the investment year; $n$ is the number of investment periods; $C f^{\prime \prime}$ is the cost of fuel in USD/year; $\mathrm{Cm}$ is the cost of vehicle maintenance in USD/year; $\mathrm{Cr}$ is the battery replacement cost, in USD/year, considering only one replacement with its cost diluted among the investment periods. The following assumptions were adopted to analyse the economic feasibility of the SOFCEV for the consumer:

- Average annual travel of $15000 \mathrm{~km} /$ year for 10 years [14],[34];

- Maintenance cost equal to 164.86 USD/year [34];

- Battery replacement after $100000 \mathrm{~km}$ of the vehicle lifetime, with the cost of $10 \%$ of the vehicle purchase price [34];

- Cost of ethanol to the consumer equal to 269.48 USD/year in Scenario A [36] and 147.29 USD/year in Scenario C;

- Cost of gasoline $C$ to the consumer equal to 295.49 USD/year in Scenario A [36] and 309.19 USD/year in Scenario $\mathrm{C}$. 
Table 1 Continuous fractional distillation simulation for carvone separation

\begin{tabular}{lcc}
\hline \multicolumn{1}{c}{ Parameter } & $\begin{array}{c}\text { Emissions } \\
\mathbf{k g} \\
\mathrm{CO} / \mathrm{km})\end{array}$ & \multicolumn{1}{c}{ Observations and Source } \\
\hline Well-to-Tank Emissions & $\begin{array}{l}\text { Souza et al. [4] conducted a vehicle life cycle } \\
\text { in Brazil; value adapted for a vehicle life cycle of 150000 } \\
\mathrm{km} .\end{array}$ \\
\hline Vehicle production & 0.0678 & $\begin{array}{l}\text { Value obtained by Souza et al. [4] and adapted for a } \\
\text { vehicle life cycle of 150000 km. }\end{array}$ \\
\hline Battery production & 0.0052 & $\begin{array}{l}\text { Garcia \& Sperling [30] estimated the average emission of } \\
\text { 2665 kg } C O_{2} \text { eq. per hectare of sugarcane, considering } \\
\text { stages such as fertilization, harvest, and transport, } \\
\text { without carbon fixation; value adapted considering agro- } \\
\text { industrial productivity, yield and fuel consumption. }\end{array}$ \\
\hline $\begin{array}{l}\text { Sugarcane ethanol } \\
\text { production in Brazil }\end{array}$ & 0.0117 & $\begin{array}{l}\text { Obtained by Souza et al. [4] and adapted for a vehicle life } \\
\text { cycle of 150000 km. }\end{array}$ \\
\hline $\begin{array}{l}\text { Gasoline } \\
\text { production in Brazil }\end{array}$ & 0.0102 & $\begin{array}{l}\text { Obtained from the ethanol steam-reforming global } \\
\text { reaction, Equation (1), Equation (8), and the average speed of LDV } \\
\text { on urban roads according to the Brazilian Traffic Code. }\end{array}$ \\
\hline SOFCEV Tank-to-wheel Emissions & $\begin{array}{l}\text { Obtained from the octane steam-reforming global } \\
\text { reaction, Equation (1), Equation (8), and the average speed of LDV } \\
\text { on urban roads according to the Brazilian Traffic Code. }\end{array}$ \\
\hline $\begin{array}{l}\text { Exhaust gas from } \\
\text { ethanol }\end{array}$ & 0.0488 &
\end{tabular}

- Motor Vehicle Property Tax (IPVA) exemption for the SOFCEV ownership in Brazil.

\subsection{Assumptions adopted}

The assumptions adopted to estimate the SOFCEV conventional LCC, NPV, WTW emissions and carbon fixed by sugarcane plantations are shown in Table 2 and Table 3. The powertrain specifications were based on the Nissan prototype ethanol-powered "e-Bio Fuel-Cell". Furthermore, the vehicle itself is based on the e-NV200, which has a 24-kWh lithium-ion battery, a SOFC output in the order of $5 \mathrm{~kW}$, a 30 -liter fuel tank capacity, and an estimated range of $600 \mathrm{~km}$ or more [37]. The density and LHV of gasoline $\mathrm{C}$ were calculated considering the volume proportion of $73 \%$ gasoline A (i.e., pure gasoline) and $27 \%$ anhydrous ethanol, resulting in $755.23 \mathrm{~kg} / \mathrm{m}^{3}$ and $38.99 \mathrm{MJ} / \mathrm{kg}$, respectively. In addition, a vehicle life cycle of $150000 \mathrm{~km}$ in 10 years of circulation was considered, without considering the cost of changing to a new cell after that period. An average agro-industrial productivity between first and second generation Brazilian ethanol was considered. Finally, for conversion purposes, the average dollar price in 2020 was adopted as 1.14 USD/EUR and 0.19 USD/BRL [38].

\section{Results and discussion}

In the present study, the conventional LCC assessment aimed to assess the possibility of the SOFCEV cost reduction based on the purchase and sale of carbon credits at a price equivalent to 0.02 USD per $\mathrm{kg}$ of $\mathrm{CO}_{2}$. According to Qiao et al. [46], it is estimated that the LCC of the BEV is $9 \%$ higher than that observed for the ICEV in 2020 in China, while in the same period, the GHG emissions of the BEV were $29 \%$ lower than that observed for an ICEV. This fact confirms the climatic benefits resulting from the advance of electromobility. The main reason for this cost difference is related to the high cost of production of the BEV, leading them to still depend on support policies and subsidies to encourage the increase of their representation in urban fleets.

Figure 3 and Figure 4 provide a comparison between the three scenarios considered in the study, which are: al Cost of investment in equipment, fuel production, and vehicle maintenance and operation in USD/ $\mathrm{km}$, over a 10-year amortization period; b) Cost of $\mathrm{CO}_{2}$ emissions of the SOFCEV from WTW added to cost (a); c) Cost of carbon fixed by hectares of sugarcane in Brazil necessary to supply the fuel demand of the SOFCEV subtracted from (b). The SOFCEV fed with ethanol (Figure 3) presented the lowest LCC in Scenario C, having benefited from the sale of carbon credits, considering the avoided cost during fuel production from carbon fixation by plantations of 
Table 2 Specifications and cost of the SOFCEV components

\begin{tabular}{cccc}
\hline Parameter & Value & Unit & Source \\
\hline Electric engine power & 40 & $\mathrm{~kW}$ & {$[14]$} \\
\hline Battery size & 24 & $\mathrm{kWh}$ & {$[37]$} \\
\hline Car shell mass & 1000 & $\mathrm{~kg}$ & {$[14]$} \\
\hline SOFC power & 5 & $\mathrm{~kW}$ & {$[37]$} \\
\hline Vehicle life cycle & 150000 & $\mathrm{~km}$ & {$[14]$} \\
\hline Electric engine cost & 1370.16 & USD & {$[14]$} \\
\hline Lithium-ion battery cost & 16441.92 & USD & {$[14]$} \\
\hline Car shell cost & 15293.95 & USD & {$[14]$} \\
\hline SOFC cost & 8943.13 & USD & {$[14]$} \\
\hline Fuel tank cost & 86.78 & USD & {$[39]$} \\
\hline SOFCEV average efficiency & 0.66 & - & {$[17]$} \\
\hline
\end{tabular}

Table 3 Other assumptions adopted in the study

\begin{tabular}{cccc}
\hline Parameter & Value & Unit & Source \\
\hline Anhydrous ethanol density & 799.40 & $\mathrm{~kg} / \mathrm{m}^{3}$ & {$[40]$} \\
\hline Gasoline A density & 737.00 & $\mathrm{~kg} / \mathrm{m}^{3}$ & {$[40]$} \\
\hline Brazilian anhydrous ethanol LHV & 28.26 & $\mathrm{MJ} / \mathrm{kg}$ & {$[40]$} \\
\hline Brazilian gasoline A LHV & 43.54 & $\mathrm{MJ} / \mathrm{kg}$ & $[40]]$ \\
\hline Ethanol production cost in Brazil & 374.33 & $\mathrm{USD} / \mathrm{m}^{3}$ & {$[41]$} \\
\hline Gasoline production cost in Brazil & 251.98 & $\mathrm{USD} / \mathrm{m}^{3}$ & {$[42]$} \\
\hline $\mathrm{CO}_{2}$ molecular weight & 44.01 & $\mathrm{~g} / \mathrm{mol}^{3}$ & - \\
\hline $\mathrm{C}_{2} \mathrm{H}_{5} \mathrm{OH}$ molecular weight & 46.07 & $\mathrm{~g} / \mathrm{mol}$ & - \\
\hline $\mathrm{C}_{8} \mathrm{H}_{18}$ molecular weight & 114.23 & $\mathrm{~g} / \mathrm{mol}$ & - \\
\hline Carbon tax & 0.02 & $\mathrm{USD} / \mathrm{kgCO}$ & {$[43]$} \\
\hline Sugarcane yield in Brazil & 74369.00 & $\mathrm{~kg} / \mathrm{ha}$ & {$[44]$} \\
\hline Ethanol agro-industrial productivity in Brazil & 7.26 & $\mathrm{~m} / \mathrm{ha}$ & {$[45]$} \\
\hline Average speed on urban roads & 40 & $\mathrm{~km} / \mathrm{h}$ & {$[21]$} \\
\hline
\end{tabular}

sugarcane. Therefore, the greater the agro-industrial ethanol productivity, the greater the benefits of carbon pricing under the vehicle LCC, since the use of agricultural waste to produce second-generation ethanol increases the volume of ethanol produced per hectare of sugarcane. Gasoline C (Figure 4) showed similar results in Scenarios A and $\mathrm{C}$. Therefore, it can be said that the use of fossil fuels, even with the addition of biofuels, does not significantly benefit from the acquisition and sale of carbon credits. In addition, the carbon fixed by plantations equivalent to the volume of sugarcane ethanol added to gasoline $C$ was responsible for making the LCC stable in Scenario $\mathrm{C}$.

According to results obtained by Qiao et al. [46], the ICEV presented a LCC of 36723.00 USD in 2020 under driving cycle in Beijing, and the BEV presented a LCC of 39935.00 USD under the same conditions. This represents an estimated LCC of $0.24 \mathrm{USD} / \mathrm{km}$ for the ICEV and 0.27 USD/km for the BEV. Under a 10-year amortization period, the SOFCEV presented an average LCC of $0.47 \mathrm{USD} / \mathrm{km}$ in Scenario C, which demonstrates a persistent lack of competitiveness compared to the vehicles analysed by Qiao et al. [46]. The high LCC of the SOFCEV is strongly related to the high cost of the components, especially the SOFC and the lithium-ion battery, so that the acquisition and sale of carbon credits is not sufficient to overcome this economic barrier.

Figure 5 shows a comparison between the fuel production cost, the emissions cost, and the avoided cost from carbon fixation in USD/vehicle. It is possible to affirm that the SOFCEV fed with ethanol reaches neutrality in the carbon cycle, since the avoided cost from the fixed $\mathrm{CO}_{2}$ emissions is 1.1 times higher than the cost of WTW emissions. The SOFCEV fed with gasoline $C$ presented an emission cost 2.5 times greater than the cost avoided by carbon fixation by sugarcane plantations. In 2019, the average production price of Brazilian ethanol was about 1.3 times higher than that observed for gasoline $C$ in the country [41, 42]. With the high avoided cost for ethanol (Figure 5), the fuel becomes more competitive than gasoline $C$ in a scenario of commercialization of carbon credits, having an ethanol production cost of around 308.18 USD/vehicle over its entire life cycle. This new cost of ethanol production is 3.8 times lower than that observed for gasoline $\mathrm{C}$ under the 


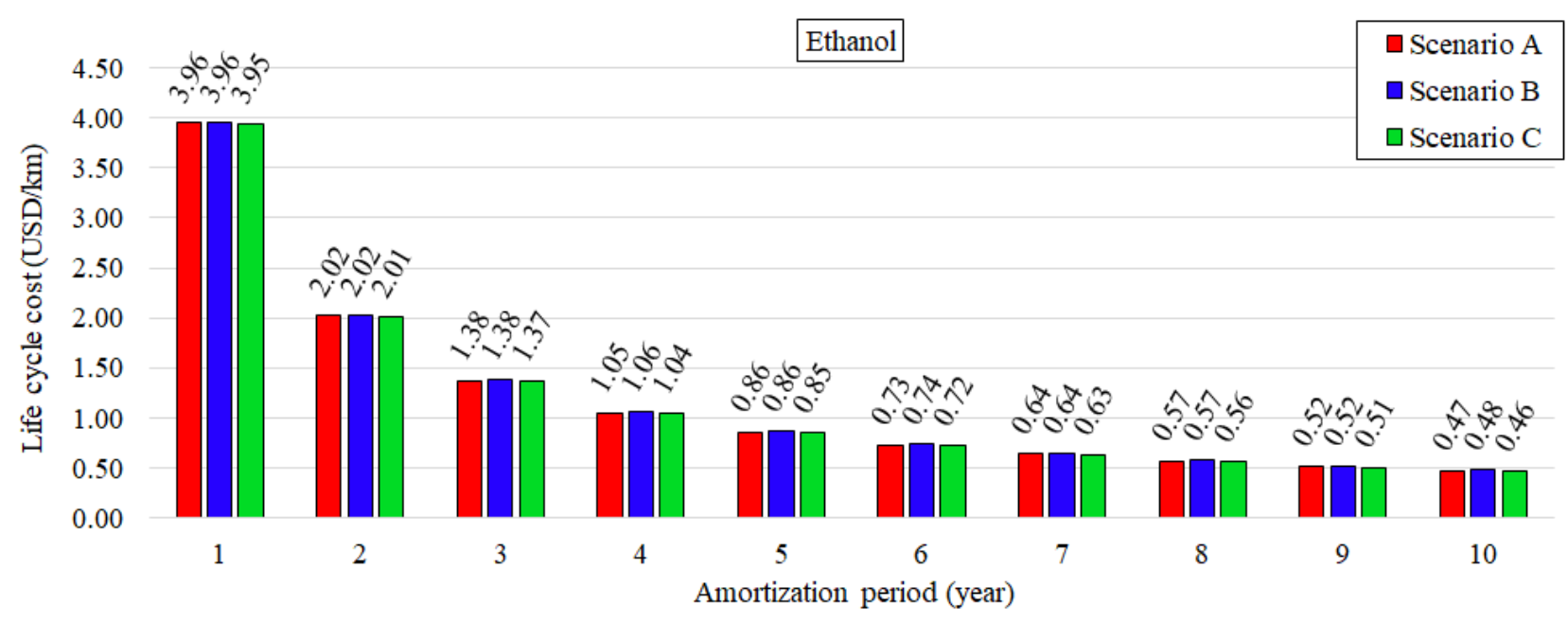

Figure 3 Life cycle cost of the SOFCEV fuelled with Brazilian ethanol

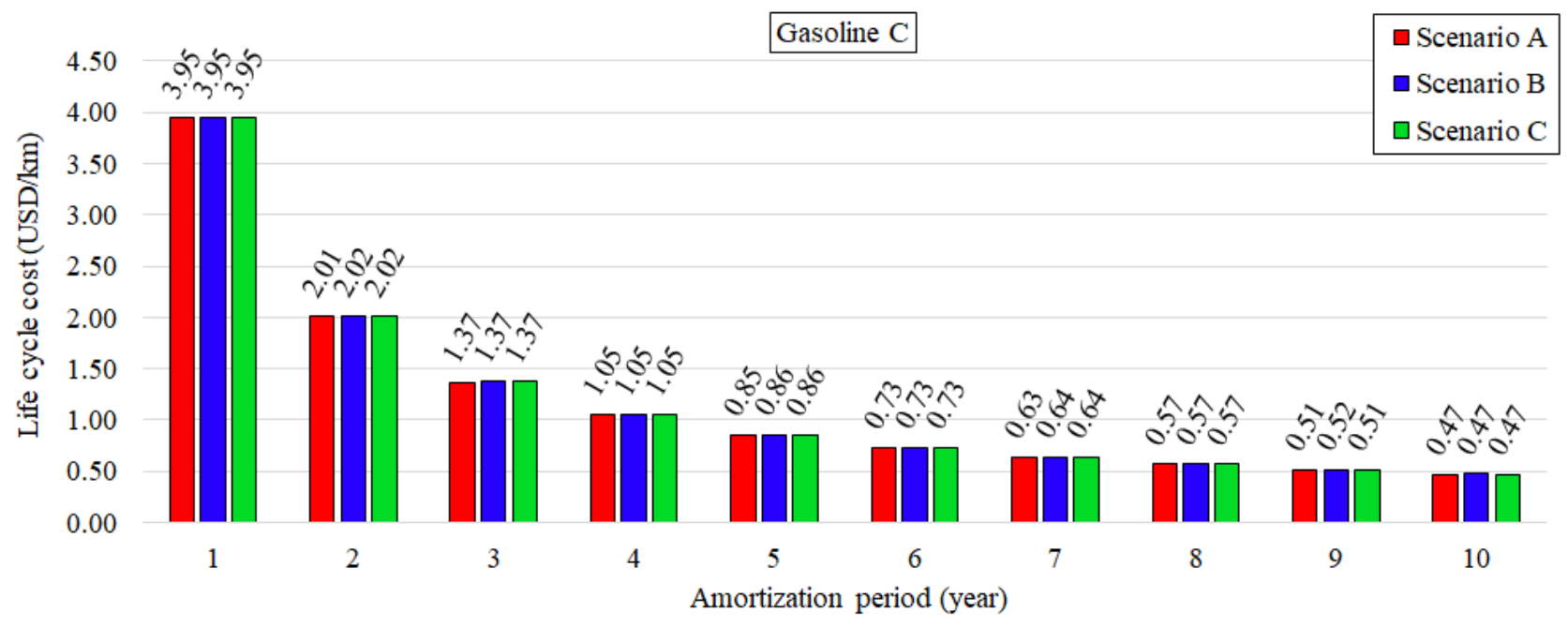

Figure 4 Life cycle cost of the SOFCEV fuelled with Brazilian gasoline C

same circumstances.

Regarding TTW emissions, the SOFCEV with an average efficiency of $66 \%$ fed with ethanol and gasoline $\mathrm{C}$ was $48.75 \mathrm{~g} \mathrm{CO}_{2} / \mathrm{km}$ and $48.34 \mathrm{~g} \mathrm{CO} / \mathrm{km}$, respectively. Such values are similar because the LHV of gasoline $\mathrm{C}$ is about $11.67 \%$ greater than that observed for ethanol, causing the flow of gasoline $C$ in the SOFCEV to be lower. Thus, the exhaust emission presented by ethanol is comparable to that of gasoline $C$, even though the latter is a fuel of predominantly fossil origin. For the Brazilian context, according to Souza et al. [4], the ICEV on Brazilian urban roads presents TTW emissions around $191 \mathrm{~g} \mathrm{CO}$ eq. $/ \mathrm{km}$ and $162 \mathrm{~g} \mathrm{CO}_{2}$ eq. $/ \mathrm{km}$ when fed with regular gasoline and E25 gasoline $175 \%$ gasoline and $25 \%$ anhydrous ethanol in volume basis), respectively. For ICEV with more developed fuel economy, emissions are around $134 \mathrm{~g} \mathrm{CO}$ eq. $/ \mathrm{km}$ when fuelled with gasoline [5].
Within the electric vehicle category, the Hybrid Electric Vehicle (HEV) and the Plug-in Electric Hybrid Vehicle (PHEV) are the main models with exhaust emissions. Both HEV and PHEV have, at the same time, one electric engine and one engine powered by internal combustion. However, HEV uses a regenerative braking system to supply electricity to the electric engine, whereas PHEV has the possibility to supply the electricity demand through external sources [47]. The light-duty HEV emits around 84 g $\mathrm{CO}_{2}$ eq. $/ \mathrm{km}$, while more modern models of light-duty PHEV have emissions in the order of $26 \mathrm{~g} \mathrm{CO}$ eq. $/ \mathrm{km}$ [5]. Therefore, TTW emissions from the SOFCEV exceed those from PHEV, but show a good result compared to TTW emissions from ICEV and HEV.

An analysis of WTW emissions is more extensive, also 


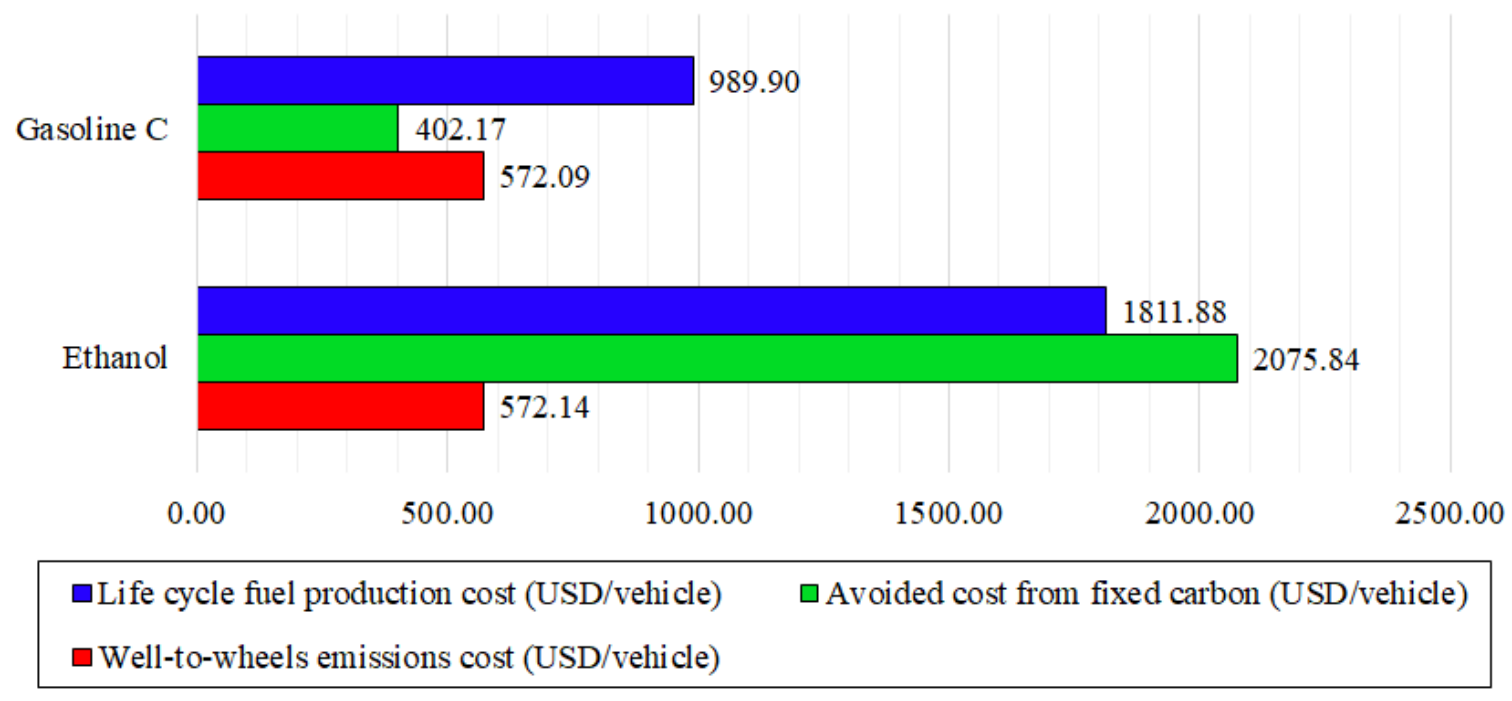

Figure 5 Comparison between the SOFCEV life cycle production cost, emissions cost, and avoided cost from carbon fixation in USD/vehicle

considering the steps that precede the supply and circulation of the vehicle. The ICEV under Brazilian conditions has WTW emissions in the order of $291 \mathrm{~g} \mathrm{CO}_{2}$ eq./ $/ \mathrm{km}$ for $\mathrm{E} 25$ gasoline and $97 \mathrm{~g} \mathrm{CO} 2$ eq. $/ \mathrm{km}$ for hydrated ethanol laddition of $5 \%$ water) [4]. In the production stage of the ICEV, approximately $50 \%$ less emissions are generated than in the production of alternative vehicles (e.g., BEV). However, this situation tends to change with the optimization of processes and the wide insertion of these new technologies in the market [5]. Choi et al. [48] reported that, for the South Korean electric matrix based on coal and with $4 \%$ renewable sources, the average WTW emissions for the BEV are $109 \mathrm{~g} \mathrm{CO}_{2}$ eq./km. Meanwhile, for the Brazilian scenario, the BEV has emissions of around $18 \mathrm{~g} \mathrm{CO}_{2}$ eq. $/ \mathrm{km}$ [49]. According to the Brazilian Energy Balance of $2018,83.2 \%$ of all national electricity produced came from renewable sources. Therefore, what justifies such low WTW emissions for BEV in circulation in Brazil is the mostly renewable national electricity matrix with a reduced carbon footprint.

WTW emissions from HFCEV can be high depending on how hydrogen is obtained. In a WTW analysis, Yoo et al. [50] reported that for the South Korean scenario, the HFCEV emissions range from 50 to $388 \mathrm{~g} \mathrm{CO}_{2}$ eq. $/ \mathrm{km}$, where hydrogen production from landfill gas generated the lowest emissions, while production by electrolysis generated the largest emissions due to the high emission factor of the national electric matrix. Nevertheless, in a scenario of high demand for hydrogen, the use of HFCEV becomes less favourable than the use of BEV, since the energy consumption of BEV in its life cycle will be lower, leaving more energy available for stationary uses [51]. Solutions such as the SOFCEV, with the insertion of fuel processor and the use of residual heat for internal reforming, could favour the dissemination of vehicles with fuel cell.

Figure 6 shows the results of economic feasibility for the Brazilian consumer obtained through the NPV method. Initially, as representative of the current scenario, the analysis was carried out without considering carbon pricing $\left(N P V_{a}\right)$, followed by an analysis considering the acquisition and sale of carbon credits by the Brazilian fuel sector $\left(N P V_{c}\right)$. It is possible to reaffirm the positive effects of carbon pricing under the ethanol chain, since the annual expenditure on ethanol goes from 263.99 USD/year to 144.29 USD/year, while gasoline $\mathrm{C}$ goes from 289.47 USD/year to 302.89 USD/year, turning ethanol into a more economically attractive biofuel to consumers.

After the 10-year period for amortizing the technology, the SOFCEV had an average NPV of -USD 8006.38. The reduction in annual fuel expenditure experienced by the ethanol-fuelled SOFCEV was not sufficient to make the technology more suitable for the Brazilian scenario. The main factor that makes the technology unfeasible is the replacement of the battery after $100000 \mathrm{~km}$ of the vehicle lifetime. According to Chiaradia [34], in 2015 a BEV in circulation in Brazil would have an NPV equal to -USD 436.37 in relation to the NPV of a conventional ICEV when stipulating the same purchase price for both, that fact corroborates for the interpretation that replacing the battery of an electric vehicle is the main factor that makes it expensive. 


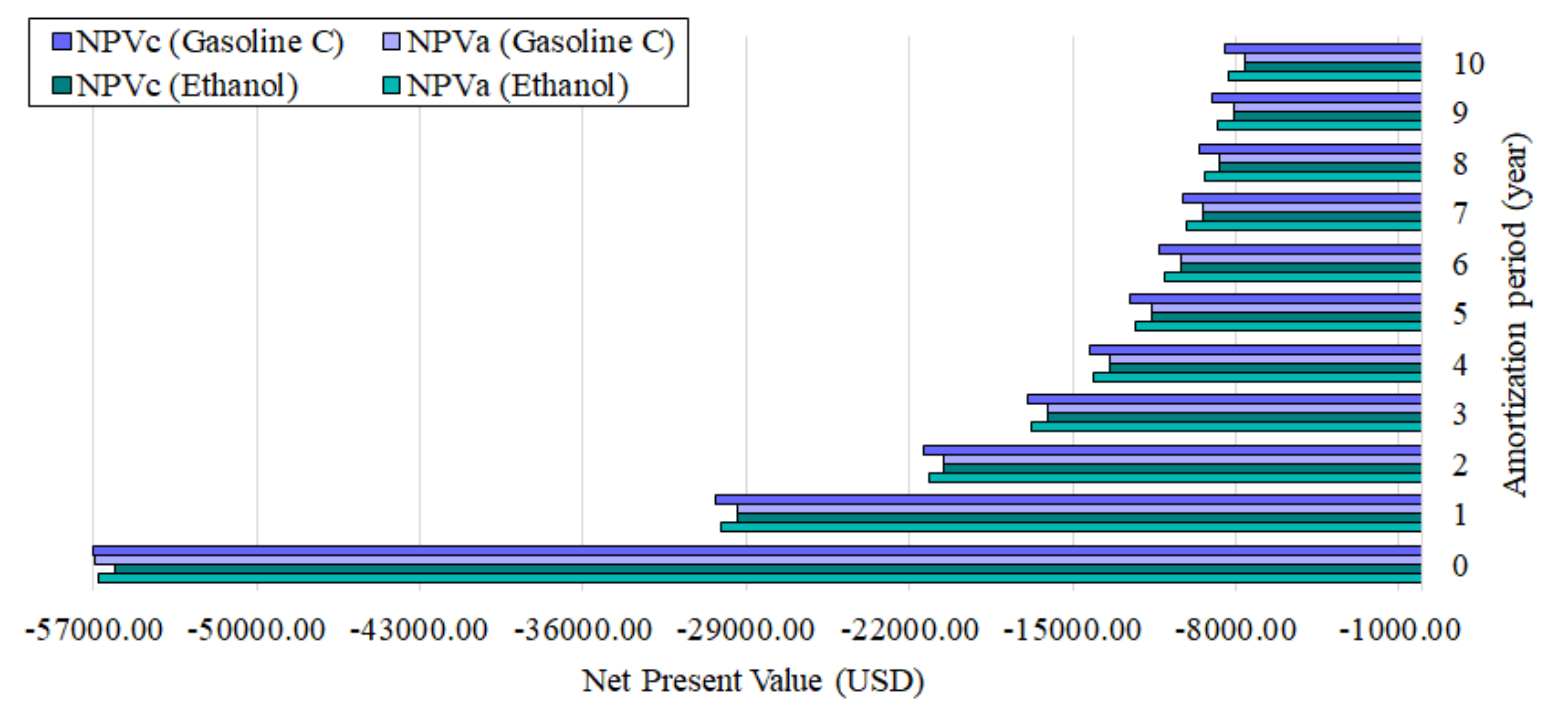

Figure 6 Economic feasibility of the SOFCEV for the Brazilian consumer

\section{Conclusion and Further Work}

A feasibility analysis (conventional LCC and NPV) of the SOFCEV fuelled with Brazilian fuels was presented together with the estimate of the vehicle TTW and WTW emissions under national conditions, considering the Brazilian sugarcane ethanol pathway. Scenarios B and C, in which carbon taxation was applied, showed a small cost difference, but indicate a better performance of biofuels compared to fossil fuels, considering the avoided cost due to carbon fixation during the cultivation of sugarcane for ethanol production. Regarding exhaust emissions, the SOFCEV with Brazilian fuels showed better results than that observed for ICEV and HEV.

It was possible to state that the SOFCEV fed with sugarcane ethanol reaches neutrality in the carbon cycle, since the avoided cost from fixed $\mathrm{CO}_{2}$ emissions is 1.1 times greater than the cost of WTW emissions. The same is not true for the SOFCEV fuelled with gasoline $C$, where the emissions cost is 2.5 times higher than the cost avoided by carbon fixation. In 2019, the average price of ethanol production surpassed that of gasoline $\mathrm{C}$, with a tax of 0.02 USD per $\mathrm{kg}$ $\mathrm{CO}_{2}$ emitted; the high avoided cost in the production of Brazilian ethanol made the fuel become more competitive than gasoline $C$, with a production cost of around 308.18 USD/vehicle. This new cost of ethanol production is 3.8 times lower than that observed for gasoline C. Finally, carbon pricing was not sufficient to make the technology more viable for consumers, with an expected NPV of -USD 8006.38 after the 10 -year amortization period.

Therefore, the study suggests that carbon pricing tends to target consumer demand for less carbon-intensive products and services, considering the better economic performance of the SOFCEV supplied with ethanol from the acquisition and sale of carbon credits. The application of the carbon taxation mechanism presents the potential to favour the use of biofuels. However, under a 10-year amortization period, the sale of carbon credits was not able to generate sufficient advantages to make the SOFCEV competitive compared to vehicles already established in the market, such as BEV and ICEV, given the high cost of powertrain production.

For further work, the analysis is indicated considering the other carbon pricing mechanisms le.g., carbon cap and carbon cap-and-trade), since carbon policies are still under development on a global scale [9], and, therefore, there is no consolidated database. In addition, the energy, economic and environmental analysis of the SOFCEV operating with other biofuels is also indicated.

\section{Declaration of competing interest}

We declare that we have no significant competing interests including financial or non-financial, professional, or personal interests interfering with the full and objective presentation of the work described in this manuscript.

\section{Acknowledgements}

The authors be very grateful to the financial support provided by the Institutional Program of Scientific Initiation Scholarships (PIBIC) from Federal Centre of Technological Education Rio de Janeiro - CEFET/RJ and the Iberoamerican Program of Science and Technology for 
Development (CYTED) with the project Smart Cities Totally Comprehensive, Efficient and Sustainable (CITIES).

\section{Funding}

This work was supported by the Institutional Program of Scientific Initiation Scholarships (PIBIC) from Federal Centre of Technological Education Rio de Janeiro CEFET/RJ and the Iberoamerican Program of Science and Technology for Development (CYTED) with the project Smart Cities Totally Comprehensive, Efficient and Sustainable (CITIES). CODE: 518RT0557.

\section{Author contributions}

D. R. Moraes, V. A. Guimarães and R. A. M. Boloy developed the theoretical database, performed the analytic calculations and the numerical simulations. $L$. Hernández-Callejo helped supervise the project. Both D. R. Moraes and B. N. Gonçalves discussed the results and contributed to the final manuscript.

\section{Data availability statement}

All the data that enabled the study execution was obtained through the Brazilian Government Agency for Support and Evaluation of Graduate Education (CAPES) portal.

\section{References}

[1] G. T. Farmer and J. Cook, Climate Change Science: A Modern Synthesis Volume 1 - The Physical Climate, 1st ed. Springer Netherlands, 2013.

[2] I. R. E. A. IRENA, Global Renewables Outlook: Energy Transformation 2050. International Renewable Energy Agency Abu Dhabi, 2020.

[3] C. A. D. Melo, G. D. M. Jannuzzi, and P. H. D. M. Santana, "Why should Brazil to implement mandatory fuel economy standards for the light vehicle fleet?" Renewable and Sustainable Energy Reviews, vol. 81, no. 1, Jan. 2018. [Online]. Available: https: //doi.org/10.1016/j.rser.2017.08.054

[4] L. L. P. de Souza and et al., "Comparative environmental life cycle assessment of conventional vehicles with different fuel options, plug-in hybrid and electric vehicles for a sustainable transportation system in Brazil," Journal of Cleaner Production, vol. 203, Dec. 1, 2018. [Online]. Available: https://doi.org/10.1016/j.jclepro.2018.08. 236

[5] D. C. Rosenfeld, J. Lindorfer, and K. Fazeni-Fraisl, “Comparison of advanced fuels-Which technology can win from the life cycle perspective?" Journal of Cleaner Production, vol. 238, Nov. 20, 2019. [Online]. Available: https://doi.org/10.1016/j.jclepro.2019.117879

[6] C. Angelo and C. Rittl, Análise das Emissões Brasileiras de Gases de Efeito Estufa e suas implicações para as metas do Brasil. SEEG, 2019.

[7] IEA. (2019, May.) Global EV Outlook 2019: scaling up the transition to electric mobility. [Online]. Available: https://www.iea.org/reports/ global-ev-outlook-2019

[8] C. V. Plaza, V. A. Guimarães, G. C. Skroder, G. M. Ribeiro, and L. da Silva, "Localização-alocação de centros de integração logística considerando critérios econômicos e ambientais," presented at 33
ANPET Congresso de Pesquisa e Ensino em Transporte da ANPET, Balneário Camboriú, Brasil, 2019.

[9] The World Bank. What is carbon pricing? Accessed Jun. 20, 2020. [Online]. Available: https://carbonpricingdashboard. worldbank.org/what-carbon-pricing

[10] CEBDS - Conselho Empresarial Brasileiro para o Desenvolvimento Sustentáve, Precificação de Carbono: o que o setor empresarial precisa saber para se posicionar, WayCarbon and R. Motta, Eds. Barra da Tijuca, Brasil: CEBDS, 2016.

[11] Partnership for Market Readiness. Accessed Ago. 17, 2020. [Online]. Available: https://www.thepmr.org/country/brazil-0

[12] ANP - Agência Nacional do Petróleo, Gás Natural e Biocombustíveis. Produção e fornecimento de biocombustíveis. Accessed Ago. 17, 2020. [Online]. Available: http://www.anp.gov.br/ producao-de-biocombustiveis/renovabio.

[13] ICCT - The International Council on Clean Transportation. (2019, Jul. 26,J Opportunities and risks for continued biofuel expansion in Brazil. Accessed Ago. 17, 2020. [Online]. Available: https: //theicct.org/publications/biofuel-expansion-Brazil

[14] Z. Dimitrova and F. Maréchal, "Environomic design for electric vehicles with an integrated solid oxide fuel cell (SOFC) unit as a range extender," Renewable Energy, vol. 112, Nov. 2017. [Online]. Available: https://doi.org/10.1016/j.renene.2017.05.031

[15] J. Wang, "Barriers of scaling-up fuel cells: Cost, durability and reliability," Energy, vol. 80, Feb. 1, 2015. [Online]. Available: https://doi.org/10.1016/j.energy.2014.12.007

[16] D. R. de Moraes, V. de Almeida, L. Hernández-Callejo, B. de Noronha, and R. A. Mancebo, "Solid Oxide Fuel Cell Electric Vehicle: Cost Reduction Based on Savings in Fixed Carbon by Sugarcane," in Proceedings of the III Ibero-American Conference on Smart Cities. Instituto Tecnológico de Costa Rica, 2020, pp. 774-789.

[17] E. Facchinetti, D. Favrat, and F. Marechal, "Innovative Hybrid Cycle Solid Oxide Fuel Cell-Inverted Gas Turbine with $\mathrm{CO}_{2}$ Separation," Fuel Cell, vol. 11, no. 4, Ago. 2011. [Online]. Available: https: //doi.org/10.1002/fuce.201000130

[18] T. Choudhary and Sanjay, "Thermodynamic assessment of SOFC-ICGT hybrid cycle: Energy analysis and entropy generation minimization," Energy, vol. 134, Sep. 1, 2017. [Online]. Available: https://doi.org/10.1016/j.energy.2017.06.064

[19] L. B. Braga, "Análise econômica do uso de célula a combustível para acionamento de ônibus urbano," M.S. thesis, Faculdade de Engenharia de Guaratinguetá, Universidade Estadual Paulista, Guaratinguetá, Brasil, 2010.

[20] R. A. M. Boloy, M. E. Silva, A. E. Valle, J. L. Silveira, and C. E. Tuna, "Thermoeconomic analysis of hydrogen incorporation in a biodiesel plant," Applied Thermal Engineering, vol. 113, Feb. 25, 2017. [Online]. Available: https://doi.org/10.1016/j.applthermaleng.2016.10.171

[21] Presidência da República Casa Civil Subchefia para Assuntos Jurídicos. (1997, Sep. 23,) Lei no 9.503 - institui o código de trânsito brasileiro. [Online]. Available: http://www.planalto.gov.br/ccivil_03/ LEIS/L9503.htm

[22] R. P. Micena, "Estação de produção e abastecimento de hidrogênio solar: análise técnica e econômica," M.S. thesis, Faculdade de Engenharia de Guaratinguetá, Universidade Estadual Paulista, Guaratinguetá, Brasil, 2020.

[23] F. A. Coutelieris, S. Douvartzides, and P. Tsiakaras, "The importance of the fuel choice on the efficiency of a solid oxide fuel cell system," Journal of Power Sources, vol. 123, no. 2, Sep. 20, 2003. [Online]. Available: https://doi.org/10.1016/S0378-7753(03)00559-7

[24] L. B. Braga, "Aspectos técnico, econômicos e ecológicos de processos de produção de hidrogênio," PhD thesis, Faculdade de Engenharia de Guaratinguetá, Universidade Estadual Paulista, Guaratinguetá, Brasil, 2014.

[25] P. Tsiakaras and A. Demin, "Thermodynamic analysis of a solid oxide fuel cell system fuelled by ethanol," Journal of Power Sources, vol. 102, no. 1-2, Dic. 2001. [Online]. Available: https: //doi.org/10.1016/S0378-7753(01)00803-5

[26] R. da P. Fiuza, M. A. Silva, L. A. M. Pontes, L. S. G. Teixeira, and J. S. Boaventura, "A utilização de etanol em célula a combustível de óxido 
sólido," Revisão Química Nova, vol. 35, no. 8, Jun. 15, 2012. [Online]. Available: https://doi.org/10.1590/S0100-40422012000800025

[27] V. Liso, G. Cinti, M. P. Nielsen, and U. Desideri, "Solid oxide fuel cell performance comparison fueled by methane, meoh, etoh and gasoline surrogate $\mathrm{c}_{8} \mathrm{~h}_{18}$," Communications Week, vol. 99, Abr. 25, 2016. [Online]. Available: https://doi.org/10.1016/j.applthermaleng. 2015.12.044

[28] S. Rabe and et al., "Catalytic reforming of gasoline to hydrogen: Kinetic investigation of deactivation processes," International Journal of Hydrogen Energy, vol. 34, no. 19, Oct. 2009. [Online]. Available: https://doi.org/10.1016/j.ijhydene.2009.07.055

[29] M. L. Carneiro and M. S. Gomes, "Energy-ecologic efficiency of waste-to-energy plants," Energy Conversion and Management, vol. 195, Sep. 1, 2019. [Online]. Available: https://doi.org/10.1016/j. enconman.2019.05.098

[30] J. C. Claros and E. V. Sperling, “Greenhouse gas emissions from sugar cane ethanol: Estimate considering current different production scenarios in Minas Gerais, Brazil," Renewable and Sustainable Energy Reviews, vol. 72, May. 2017. [Online]. Available: https://doi.org/10.1016/j.rser.2017.01.046

[31] T. Neamhom, C. Polprasert, and A. J. Englande, "Ways that sugarcane industry can help reduce carbon emissions in Thailand," Journal of Cleaner Production, vol. 131, Sep. 10, 2016. [Online]. Available: https://doi.org/10.1016/j.jclepro.2016.04.142

[32] EPA-United States Environmental Protection Agency. Greenhouse Gases Equivalencies Calculator - Calculations and References. Accessed Ago. 19, 2020. [Online]. Available: https://bit.ly/3jyLG1T

[33] T. Larriba, R. Garde, and M. Santarelli, "Fuel cell early markets: Techno-economic feasibility study of PEMFC-based drivetrains in materials handling vehicles," International Journal of Hydrogen Energy, vol. 38, no. 5, Feb. 19, 2013. [Online]. Available: https: //doi.org/10.1016/j.ijhydene.2012.11.048

[34] C. E. Chiaradia, "Estudo da viabilidade da implantação de frotas de veículos elétricos e híbridos elétricos no atual cenário econômico, político, energético e ambiental brasileiro," Undergraduate thesis, Faculdade de Engenharia de Guaratinguetá, Universidade Estadual Paulista, Guaratinguetá, Brasil, 2015.

[35] Y. Chaves, "Análise de viabilidade de um sistema híbrido alimentado por biogás e energia solar," M.S. thesis, Instituto Politécnico de Bragança, Bragança, Portugal, 2020.

[36] G. N. e. B. B. Agência Nacional do Petróleo, Anuário estatístico brasileiro do petróleo, gás natural e biocombustíveis: 2020 . Rio de Janeiro, Brasil: ANP, 2020.

[37] Nissan Motor Corporation. (2016, Jun. 14,) Nissan announces development of the world's first SOFC-powered vehicle system that runs on bio-ethanol electric power. Accessed Jun. 1, 2020. [Online]. Available: https://global.nissannews.com/en/releases/ 160614-01-e?source=nng\#\&\&.

[38] S. Bubeck, J. Tomaschek, and U. Fahl, "Perspectives of electric mobility: Total cost of ownership of electric vehicles in Germany," Transport Policy, vol. 50, Ago. 2016. [Online]. Available: https: //doi.org/10.1016/j.tranpol.2016.05.012

[39] G. N. e. B. ANP-Agência Nacional do Petróleo. Renovabio. Accessed Jun. 10, 2020. [Online]. Available: http://www.anp. gov.br/producao-de-biocombustiveis/renovabio/renovacalc.
[40] CEPEA-Center for Advanced Studies in Applied Economics. Etanol. Accessed Ago. 21, 2020. [Online]. Available: https://www.cepea. esalq.usp.br/br/indicador/etanol.aspx

[41] G. N. e. B. B. Agência Nacional do Petróleo, Anuário estatístico brasileiro do petróleo, gás natural e biocombustíveis: 2019. Rio de Janeiro, Brasil: APN, 2019.

[42] C. Redriguez, C. E. Tuna, R. Zanzi, L. F. Vane, and J. L. Silveira, "Development of a thermoeconomic methodology for optimizing biodiesel production. Part II: Manufacture exergetic cost and biodiesel production cost incorporating carbon credits, a Brazilian case study," Renewable and Sustainable Energy Reviews, vol. 29, Ene. 2014. [Online]. Available: https://doi.org/10.1016/j.rser.2013.08.064

[43] FAO-Food and Agriculture Organization of the United Nations. Food and agriculture data. Accessed Ago. 21, 2020. [Online]. Available: http://www.fao.org/faostat/en/\#data

[44] C.-C. for Strategic Studies and Management, Second-generation sugarcane bioenergy y biochemicals: Advanced lowcarbon fuels for transport and industry. Brasilia: Center for Strategic Studies and Management, 2017.

[45] Q. Qiao and et al., "Costo del ciclo de vida y beneficios de las emisiones de GEI de los vehículos eléctricos en China," Investigación sobre transporte Parte D: Transporte y medio ambiente, vol. 86, Sep. 2020. [Online]. Available: https://doi.org/10.1016/j.trd.2020.102418

[46] D. R. de Moraes, R. Boloy, and G. M. Ribeiro, "Electromobility: A review on electric vehicle technologies and potentialities for the brazilian scenario," in Efficient, Sustainable, and Fully Comprehensive Smart Cities. II Ibero-American Congress of Smart Cities. Cali: Universidad Santiago de Cali, 2020, pp. 658-669.

[47] W. Choi, E. Yoo, E. Seol, M. Kim, and H. H. Song, “Greenhouse gas emissions of conventional and alternative vehicles: Predictions based on energy policy analysis in South Korea," Applied Energy, vol. 265, May. 1, 2020. [Online]. Available: https://doi.org/10.1016/j. apenergy.2020.114754

[48] A. C. Teixeira and J. R. Sodré, "Impacts of replacement of engine powered vehicles by electric vehicles on energy consumption and $\mathrm{CO}_{2}$ emissions," Transportation Research Part D: Transport and Environment, vol. 59, Mar. 2018. [Online]. Available: https: //doi.org/10.1016/j.trd.2018.01.004

[49] Empresa de Pesquisa Energética (Brasil), Balanço Energético Nacional 2019: Ano base 2018. Rio de Janeiro, Brasil: EPE, 2019.

[50] M. F. Felgenhauer, M. A. Pellow, S. M. Benson, and T. Hamacher, "Economic and Environmental Prospects of Battery and Fuel Cell Vehicles for the Energy Transition in German Communities," Energy Procedia, vol. 99, Nov. 2016. [Online]. Available: https: //doi.org/10.1016/j.egypro.2016.10.128

[51] ECB-European Central Bank. (2021) ECB/Eurosystem policy and exchange rates. Accessed Abr. 8, 2021. [Online]. Available: https://www.ecb.europa.eu/stats/policy_and_exchange_ rates/html/index.en.html

[52] E. Yoo, M. Kim, and H. H. Song, "Well-to-wheel analysis of hydrogen fuel-cell electric vehicle in Korea," International Journal of Hydrogen Energy, vol. 43, no. 41, Oct. 11, 2018. [Online]. Available: https://doi.org/10.1016/j.ijhydene.2018.08.088 